\title{
The Empowerment of Critical and Creative Thinking (CCT) Skills in Indonesian Language Learning: A Case Study of Online Learning in Secondary School During the COVID-19 Pandemic
}

\author{
Bambang Riadi \\ Department of Laanguage and Arts \\ Education \\ Lampung University \\ Lampung, Indonesia \\ bambang.riadi@fkip.unila.ac.id
}

\author{
Rian Andri Prasetya \\ Department of Laanguage and Arts \\ Education \\ Lampung University \\ Lampung, Indonesia \\ rian.andri@fkip.unila.ac.id
}

\author{
Rahmat Prayogi \\ Department of Laanguage and Arts \\ Education \\ Lampung University \\ Lampung, Indonesia \\ rahmat.prayogi@fkip.unila.ac.id
}

\author{
Ryzal Perdana \\ Educational Science \\ Lampung University \\ Lampung, Indonesia \\ ryzalperdana@fkip.unila.ac.id
}

\begin{abstract}
Many studies have been conducted to determine students' critical and creative thinking skills. However, no one has discussed empowering critical and creative thinking skills in online learning during the covid 19 pandemics. Therefore, we aim to explain how students' critical and creative thinking skills learn Indonesian online during the covid 19 pandemics. We use the method qualitative descriptive to analyze the data obtained from the test. The results showed that the students' critical and creative thinking skills had not empowered most students. Therefore, teachers need to design online learning in such a way as to make it easier for students to interact with both teachers and other students actively. The implications of this study are also discussed, along with some recommendations for future studies.
\end{abstract}

Keywords-critical and creative thinking (CCT) skills, Online Learning, Indonesian language learning, Covid-19

\section{INTRODUCTION}

Education in the era of the industrial revolution 4.0 is directed at developing 21 st-century competencies [1], [2]. Students must master the following 21 st century skills: (1) critical thinking, which aims to teach students how to solve various contextual problems using critical and rational logic; (2) creativity, which aims to teach students how to be creative in finding various solutions, designing new strategies, or finding ways that have not previously been used; (3) collaboration, which enables students to work in groups, tolerance, and understanding differences; and (4) critical thinking, which aims to teach students how to solve various contextual problems using critical and rational logic [3$8]$.

Critical thinking skills are important in education because these skills can enable students actually to understand more complex information. Students can also share the results of ideas with others and describe social critical thinking [9-11]. Critical thinking skills will guide students to find and summarize their own understanding, and high critical thinking skills will also make students more easily accepted in the work environment [12-14].

Furthermore, creative thinking is an important part of one's life to solve problems in everyday life [15]. By thinking creatively, one can create something new and different from others [16]. Therefore, creative thinking is critical to be realized in learning at school [17].

Indonesian language learning in the 2013 curriculum is directed to develop language skills that make students lifelong independent, creative, and able to solve problems skillfully in Indonesian [18]. It should also be noted that in its implementation, Indonesian language learning uses a text-based approach. With text-based, students use language as a means of communication and a means of developing 
thinking skills [18]. Thus, learning Indonesian needs to empower critical and creative thinking skills to solve problems and innovate in everyday life.

To see students' critical and creative thinking skills, six aspects must be measured: Problem sensitivity, Analysis, Inferences, Make Elaboration, Evaluation, and Novelty (PAIMEN) [17, 19].

However, the COVID-19 pandemic that hit Indonesia forced teachers in senior high schools to do online learning. Many problems arise in implementing online learning, such as internet access, finance, and the lack of interaction between teachers and students [20, 21]. These various problems can certainly affect learning outcomes, especially the ability to think critically and creatively. The study results explain that online learning using various platforms such as Webex, Google Zoom, Google Meet affects student learning outcomes [22]. In addition, other studies explain that there is a relationship between critical thinking and the use of social media as a learning tool with student learning outcomes [23]. However, no research explains how students' critical and creative thinking skills in online learning during the covid 19 pandemics. Thus, it is necessary to study more deeply the creative and critical thinking skills of high school students in learning Indonesian in the era of the covid-19 pandemic.

\section{LITERATURE REVIEW}

\section{A. Definition of Empowerment}

Empowerment is a word that means the development of a person or group to achieve certain goals that go through a process and get results from what they do [24]. Empowerment is a term related to the abilities and skills that a person can do in learning through activities carried out together, with peers, or more skilled in these activities to achieve a goal of learning that he does [25].

The empowerment referred to in this study is an aspect of students' critical thinking and creative thinking skills, which are expected to become an ability possessed by students through learning activities designed and can be used in everyday life. Empowerment is done by connecting the strengths possessed by students who behave proactively towards social change to achieve an expected ability in learning objectives [26].

\section{B. Critical and Creative Thinking (CCT) Skills}

There are six sorts of critical thinking skills that must be acquired in order to have effective critical thinking skills. Analysis, inference, interpretation, explanation, self-regulation, and appraisal are among these abilities [27]. Fluency, Flexibility, Originality, and Elaboration are four dimensions of creative thinking talents [28, 29]. Fluency is defined as the ability to generate a large number of ideas quickly. The ability to develop a variety of ideas is referred to as flexibility. Originality is the capacity to come up with responses to concepts that are uncommon or distinctive among most people. The ability to develop and communicate a concept is known as elaboration.

Another opinion explains that creative thinking and critical thinking skills consist of six aspects: Problem sensitivity, Analysys, Inferences, Make Elaboration, Evaluation dan Novelty (PAIMEN) [17, 19]. These six aspects can be described in the following table.

TABLE I. CONCEPTUAL CONSTRUCTION OF CREATIVE AND CRITICAL THINKING (CCT) SKILLS [17]

\begin{tabular}{|l|l|l|}
\hline \multicolumn{1}{|c|}{ Aspect } & \multicolumn{1}{|c|}{ Description } & \multicolumn{1}{c|}{ Indicator } \\
\hline $\begin{array}{l}\text { Problem } \\
\text { sensitivity }\end{array}$ & $\begin{array}{l}\text { The ability to detect and } \\
\text { generate a unique idea from a } \\
\text { question or situation it faces. }\end{array}$ & $\begin{array}{l}\text { Generate unique ideas or ideas } \\
\text { from the questions it faces } \\
\text { (Fluency) } \\
\text { Predict the view of a problem } \\
\text { from multiple perspectives } \\
\text { (Flexibility). }\end{array}$ \\
\hline Analysis & $\begin{array}{l}\text { Ability to identify the truth- } \\
\text { between questions and } \\
\text { concepts and can state } \\
\text { decisions with the right } \\
\text { information }\end{array}$ & $\begin{array}{l}\text { Identify evidence-based on } \\
\text { existing data. (Interpretation) }\end{array}$ \\
$\begin{array}{ll}\text { Linking the reasons for or } \\
\text { against decisions made based } \\
\text { on facts. (Reason). }\end{array}$ \\
\hline $\begin{array}{l}\text { Inferences ability to explain the truth } \\
\text { between the data and the } \\
\text { applicable theory and be able } \\
\text { to defend his opinion to be } \\
\text { accepted by others }\end{array}$ & $\begin{array}{l}\text { Explain the meaning of terms } \\
\text { used (Clarity) } \\
\text { The sharpness of understanding } \\
\text { to be able to communicate to } \\
\text { others (Insight) }\end{array}$ \\
\hline $\begin{array}{l}\text { Make } \\
\text { Elaboration }\end{array}$ & $\begin{array}{l}\text { The ability to describe } \\
\text { something in more detail to be } \\
\text { understood by others }\end{array}$ & $\begin{array}{l}\text { Develop something to be better } \\
\text { understood by himself or } \\
\text { others (Generating) } \\
\text { Reviewing an issue based on a } \\
\text { different perspective or the } \\
\text { same as other people so that it } \\
\text { be } \\
\text { can understood } \\
\text { (Redefinition) }\end{array}$ \\
\hline
\end{tabular}




\begin{tabular}{|l|l|l|}
\hline Evaluation & $\begin{array}{l}\text { The ability to judge the } \\
\text { credibility of a question or } \\
\text { presentation by describing } \\
\text { one's perceptions, experiences, } \\
\text { situations, decisions, beliefs } \\
\text { and assessing the logical } \\
\text { strength of actual inferential } \\
\text { relationships or other forms of } \\
\text { representation. }\end{array}$ & $\begin{array}{c}\text { Awares in understanding } \\
\text { their abilities (Self-regulated) } \\
\text { Thoroughly re-examine the } \\
\text { decisions are taken (Overview) }\end{array}$ \\
\hline Novelty & $\begin{array}{l}\text { The ability to make or finish } \\
\text { something differently but has } \\
\text { the value of truth or usefulness. }\end{array}$ & $\begin{array}{l}\text { Produce or complete something } \\
\text { itself because it is rarely used by } \\
\text { most people (Originality) }\end{array}$ \\
\hline
\end{tabular}

\section{Learning Online During Covid-19}

The COVID-19 pandemic, which has swept the globe, including Indonesia, has had an influence on schooling. In order to avoid the spread of Corona Virus Disease, the Indonesian government issued Circular Letters of the Minister of Education and Culture Number 3 of 2020 addressing the prevention of Covid19 in educational units and Number 36962/MPK.A/HK/2020 concerning online learning and working from home (Covid-19). As a result, online learning is required from elementary school to university.

This condition makes teachers try to find methods or learning strategies to take place with the same quality as when learning is carried out offline. Teachers often use online learning media are WhatsApps, Zoom Meeting, Microsoft Teams, Google Classroom, TeamLink, Kaizala Microsoft, Youtube, and others [30]. Online learning is a deep solution to prevent the spread of covid-19, but it is not as effective as conventional learning [31]. Many obstacles occur in the implementation of online learning. From the student's perspective, the main obstacle they face is the internet network and the lack of interaction between teachers to students or students to students [31].

\section{THE STUDY}

This research was carried out in one of the public high schools in Bandar Lampung, Class X SMA Negeri 9 Bandar Lampung, with a total of 74 students. This study used the descriptive qualitative method. Qualitative research uses a naturalistic approach to seek and understand phenomena in specific contextual settings [32]. In this case, the researcher wants to know the empowerment of creative and critical thinking skills of high school students in learning Indonesian. The test technique is done by giving a set of tests in the form of questions to measure critical and creative thinking skills. The data obtained were then analyzed using the following criteria.

$$
\begin{gathered}
\text { Student scores }= \\
\frac{\text { Score obtained }}{\text { Maximum Score }} \times 100 \%
\end{gathered}
$$

To find out the categories of students' critical and creative thinking abilities, we refer to the following table.

TABLE II. LEVEL CRITERIA OF CREATIVE AND CRITICAL THINKING (CCT) SKILLS [33]

\begin{tabular}{|c|c|c|}
\hline No & Percentage scale & Category \\
\hline 1 & $86 \%-100 \%$ & Very Good \\
\hline 2 & $76 \%-85 \%$ & Good \\
\hline 3 & $60 \%-75 \%$ & Moderate \\
\hline 4 & $55 \%-59 \%$ & Poor \\
\hline 5 & $\leq 54 \%$ & Very Poor \\
\hline
\end{tabular}

In summary, the procedure for this research can be seen in the image below.

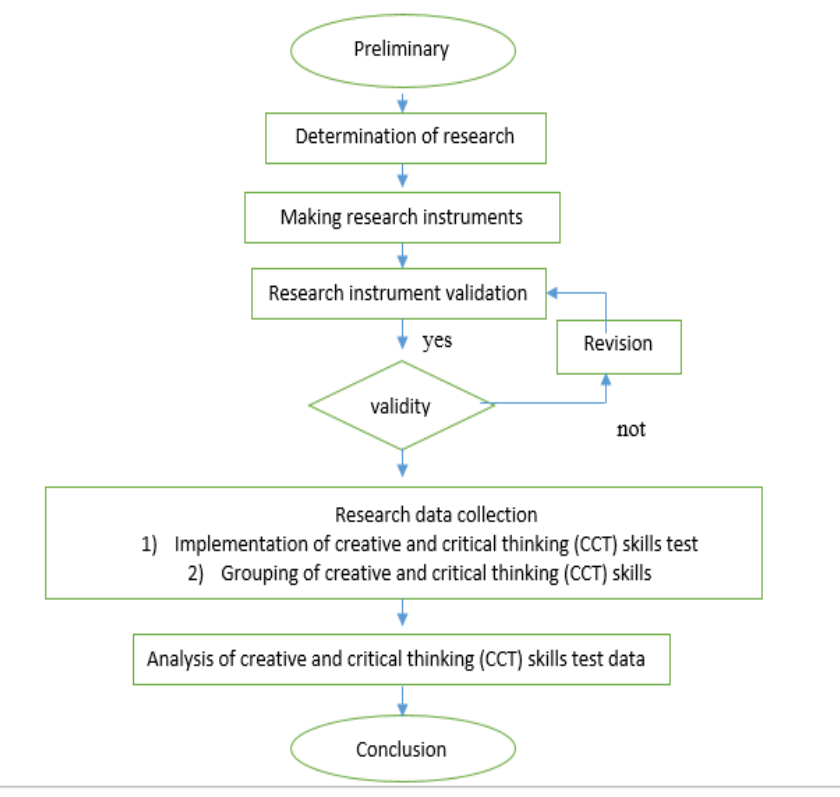

Fig. 1. Research procedure 


\section{FINDINGS}

The results of students' creative and critical thinking (CCT) skills can be known after the test results are analyzed and measured based on the guidelines for critical and creative thinking. The empowerment of critical and creative thinking per aspect can be seen in the table below.

TABLE III. AVERAGE PERCENTAGE SCORE INDICATOR OF STUDENTS' CREATIVE AND CRITICAL THINKING (CCT) SKILLS

\begin{tabular}{|c|c|c|c|c|}
\hline No & \multicolumn{2}{|c|}{ Aspect CCT/Indicator } & $\begin{array}{c}\text { Aspect Average } \\
(\%)\end{array}$ & Category \\
\hline \multirow{2}{*}{1} & \multirow{2}{*}{$\begin{array}{l}\text { Problem } \\
\text { sensitivity }\end{array}$} & Fluency & $67 \%$ & Moderate \\
\hline & & Flexibility & $59 \%$ & Poor \\
\hline \multirow{2}{*}{2} & \multirow{2}{*}{ Analysis } & Interpretation & $65 \%$ & Moderate \\
\hline & & Reason & $57 \%$ & Poor \\
\hline \multirow{2}{*}{3} & \multirow{2}{*}{ Inferences } & Clarity & $61 \%$ & Moderate \\
\hline & & Insight & $60 \%$ & Moderate \\
\hline \multirow{2}{*}{4} & \multirow{2}{*}{$\begin{array}{l}\text { Make } \\
\text { Elaboration }\end{array}$} & Generating & $65 \%$ & Moderate \\
\hline & & Redefinition & $58 \%$ & Poor \\
\hline \multirow{2}{*}{5} & \multirow{2}{*}{ Evaluation } & Self regulated & $63 \%$ & Moderate \\
\hline & & Overview & $58 \%$ & Poor \\
\hline 6 & Novelty & Orrriginality & $58 \%$ & Poor \\
\hline
\end{tabular}

The table above shows the empowerment of respondents' creative and critical thinking skills (CCT) in various aspects. The fluency indicator is in the moderate category $(67 \%)$, while the flexibility is in the poor category $(59 \%)$. The analysis aspect of the interpretation indicator is in the moderate category $(65 \%)$, while the reasons are in the poor category $(57 \%)$. The inference aspect of the indicators of clarity and insight is moderate $(61 \%$ and $60 \%)$. Aspects of elaboration and redefinition indicators are in the moderate and poor categories (65\% and 58\%). The evaluation aspect of self-regulation indicators is in the moderate category $(63 \%)$, while the generating is in the poor category $(58 \%)$. The novelty aspect is categorized as poor $(58 \%)$. Thus, the students' critical and creative thinking skills are mostly in the moderate category. It can be seen that all aspects of critical and creative thinking in Indonesian language learning need to be improved.

Based on the data analysis that has been done, it can be seen that the creative and critical thinking (CCT) skills of each research subject have different achievements. The distribution of the frequency of students' critical and creative thinking abilities as a whole can be seen in the table below.
TABLE IV FREQUENCY DISTRIBUTION OF STUDENTS' CRITICAL AND CREATIVE THINKING (CCT) SKILLS

\begin{tabular}{|c|c|c|c|}
\hline No & Frequency & Percentage & Category \\
\hline 1 & 8 & $11 \%$ & Good \\
\hline 2 & 32 & $43 \%$ & Moderate \\
\hline 3 & 34 & $46 \%$ & Poor \\
\hline
\end{tabular}

The table shows that most of the respondents' creative and critical thinking (CCT) skills are in the poor category, and only a few are good. Thus, students' creative and critical thinking (CCT) skills in online Indonesian language learning during the COVID-19 pandemic have not been empowered.

\section{DISCUSSION}

Need to know to measure creative and critical thinking (CCT) skills of students, this study classifies into five categories that are very good, well, moderate, poor, and very poor [33], while creative and critical thinking (CCT) skills students are seen from several aspects namely Problem sensitivity (Fluency and Flexibility), Analysis (Interpretation and Reason), Inferences (Clarity and Insight), Make Elaboration (Generating and Redefinition), Evaluation (Selfregulated and Overview), and Novelty (Originality) [17].

Based on the analysis of data on the study results, it is known that creative and critical thinking (CCT) skills students who are in the category of moderate on the indicators Fluency, Interpretation, Clarity, Insight, 
Generating, and Self-regulated. This data shows that some students have been able to generate unique ideas from fluency, identify evidence from existing data (interpretation), explain the meaning of a term used (clarity), acuity of understanding to be communicated to others (insight), develop ideas to be able to understand others (generating) and assess the credibility of questions based on their ability (selfregulated)

In addition, creative and critical thinking (CCT) skills students in the poorer category are on the indicators Flexibility, Reason, Redefinition, Overview, and Originality. The data explains that students are still poor able to predict the view of a problem (flexibility), make reasons that support the answer or decision made (reason), review a problem from a different perspective (redefinition), examine the decision taken (overview), and produce something new (originality).

If you look at the perspective, then creative and critical thinking (CCT) skills students are diverse. But no students have been in the category of very good or well. They are at their highest in the category of quite even some are in the poor category. Thus, creative and critical thinking (CCT) skills students still need to be improved and have not empowered in learning the Indonesian language.

Seeing these conditions, online learning during the COVID-19 pandemic has not empowered critical and creative thinking skills, especially in learning Indonesian. Of course, many factors cause this to happen. The weakness of online learning is the lack of interaction between teachers and students [20]. In addition, another problem is when they have to discuss without face to face with other students[20]. Teachers also realize that their online learning is not yet fully effective, and they are also trying to improve their technological competence in the future [34]. Online pedagogy and teachers' digital skills need to be improved to improve the quality of their learning [35] so that online learning can improve students' critical and creative thinking skills, such as face-to-face learning.

\section{CONCLUSION}

During the Covid 19 pandemic, online learning has not been able to empower students' critical and creative thinking skills. The test results on students as respondents showed that $46 \%$ of students were in the poor category, and none were good. Students' weaknesses can be seen in the indicators of Flexibility, Reason, Redefinition, Overview, and Originality. Online learning does help teachers in implementing learning in schools and can prevent the spread of covid 19. However, teachers' readiness in online learning causes learning outcomes to be unable to improve students' critical and creative thinking skills.

This study has several implications. Because it was found that critical and creative thinking skills have not been well empowered in most students, teachers should design online learning as well as possible while still facilitating students to interact with each other both between teachers and students and students with students. In addition, teachers can increase their knowledge of technological pedagogical content (TPACK) to create interesting learning content.

However, this research has limitations. Although this research has explained students' critical and creative thinking skills who have not been empowered in learning in Lampung, this study only applies to the sample that we took. In other words, we do not generalize our findings across Lampung and even Indonesia. Therefore, it is necessary to conduct critical and creative thinking empowerment research with many participants.

\section{ACKNOWLEDGMENT}

We want to thank all respondents for taking part in this study. We also thank the University of Lampung LPPM for funding this research.

\section{REFERENCES}

[1] G K. Beswick and S. Fraser, "Developing mathematics teachers' 21 st century competence for teaching in STEM contexts," ZDM, vol. 51, no. 6, pp. 955-965, 2019.

[2] E. Care, H. Kim, A. Vista, and K. Anderson, "Education System Alignment for 21st Century Skills: Focus on Assessment," Center for Universal Education at The Brookings Institution, 2018.

[3] L. C. Larson and T. N. Miller, "21st century skills: Prepare students for the future," Kappa Delta Pi Record, vol. 47, no. 3 , pp. 121-123, 2011.

[4] D. W. Happ, "Results of a survey of 21 st century skills of communication, collaboration, critical thinking, and creativity," American International College, 2013.

[5] K. F. Geisinger, "21st century skills: What are they and how do we assess them?," Applied Measurement in Education, vol. 29, no. 4, pp. 245-249, 2016.

[6] S. Sajidan and A. Afandi, "Pengembangan Model Pembelajaran Ipa Untuk Memberdayakan Keterampilan Berpikir Tingkat Tinggi," in Prosiding SNPS (Seminar Nasional Pendidikan Sains), 2017, pp. 15-27.

[7] B. Trilling and C. Fadel, 21st Century Skills, Enhanced Edition: Learning for Life in Our Times. John Wiley \& Sons, 2009.

[8] S. A. Vong and W. Kaewurai, "Instructional model development to enhance critical thinking and critical thinking teaching ability of trainee students at regional teaching training center in Takeo province, Cambodia," Kasetsart Journal of Social Sciences, vol. 38, no. 1, pp. 88-95, 2017.

[9] C. P. Dwyer, M. J. Hogan, and I. Stewart, "An integrated critical thinking framework for the 21st century," Thinking skills and Creativity, vol. 12, pp. 43-52, 2014.

[10] S. A. Forawi, "Standard-based science education and critical thinking," Thinking Skills and Creativity, vol. 20, pp. 52-62, 2016.

[11] J. J. Vaske and K. C. Kobrin, "Place attachment and environmentally responsible behavior," The Journal of Environmental Education, vol. 32, no. 4, pp. 16-21, 2001

[12] N. C. Facione and P. A. Facione, Critical thinking assessment in nursing education programs: An aggregate data analysis. California Academic Press, 2000. 
[13] P. A. Facione, N. C. Facione, and C. A. F. Giancarlo, "The motivation to think in working and learning," New directions for higher education, pp. 67-80, 1996.

[14] S. ŽivkoviL, "A model of critical thinking as an important attribute for success in the 21 st century," Procedia-social and behavioral sciences, vol. 232, pp. 102-108, 2016.

[15] J. C. Kaufman, J. A. Plucker, and C. M. Russell, "Identifying and assessing creativity as a component of giftedness," Journal of psychoeducational assessment, vol. 30, no. 1, pp. 60-73, 2012.

[16] E. Aldig and A. Arseven, "The Contribution of Learning Outcomes for Listening to Creative Thinking Skills," Journal of Education and Learning, vol. 6, no. 3, pp. 41-53, 2017.

[17] R. Perdana, "Pengembangan model pembelajaran Inquiry Social Complexity (ISC) untuk memberdayakan Critical and Creative Thinking (CCT) skills," UNS (Sebelas Maret University), 2020.

[18] S. Budiyono, "Pengembangan Buku Ajar Keterampilan Membaca dengan Pembelajaran Berbasis Teks (Text Based Learning)," UNS (Sebelas Maret University), 2018.

[19] R. Perdana, "Analysis of Student Critical and Creative Thinking (CCT) Skills on Chemistry: A Study of Gender Differences," Journal of Educational and Social Research, vol. 9, no. 4, pp. 43-43, 2019.

[20] M. Adnan and K. Anwar, "Online Learning amid the COVID19 Pandemic: Students' Perspectives," Online Submission, vol. 2, no. 1, pp. 45-51, 2020.

[21] M. D. G. Allo, "Is the online learning good in the midst of Covid-19 Pandemic? The case of EFL learners," Jurnal Sinestesia, vol. 10, no. 1, pp. 1-10, 2020.

[22] D. L. Edy, "Revisiting the impact of project-based learning on online learning in vocational education: analysis of learning in pandemic Covid-19," in 2020 4th International Conference on Vocational Education and Training (ICOVET), 2020: IEEE, pp. 378-381.

[23] B. Nadeak, C. P. Juwita, E. Sormin, and L. Naibaho, "Hubungan kemampuan berpikir kritis mahasiswa dengan penggunaan media sosial terhadap capaian pembelajaran pada masa pandemi Covid-19," Jurnal Konseling dan Pendidikan, vol. 8, no. 2, pp. 98-104, 2020.

[24] [24] C. Eger, G. Miller, and C. Scarles, "Gender and capacity building: A multi-layered study of empowerment," World Development, vol. 106, pp. 207-219, 2018.

[25] A. Simmons, R. C. Reynolds, and B. Swinburn, "Defining community capacity building: is it possible?," Preventive medicine, vol. 52, no. 3-4, pp. 193-199, 2011.

[26] A. Wilkinson, "Empowerment: theory and practice," Personnel review, 1998.

[27] P. A. Facione, "The California Critical Thinking Skills Test-College Level. Technical Report\# 1. Experimental Validation and Content Validity," 1990.

[28] E. P. Torrance, "Creativity in the Classroom; What Research Says to the Teacher," 1977.

[29] E. P. Torrance, "Teaching for creativity," Frontiers of creativity research: Beyond the basics, vol. 189, p. 215, 1987.

[30] F. Fahmalatif, A. Purwanto, E. Siswanto, and J. Ardiyanto, "Exploring Barriers and Solutions of Online Learning During the Covid-19 Pandemic By Vocational School Teachers," Journal of Industrial Engineering \& Management Research, vol. 2, no. 2, pp. 53-63, 2021.

[31] P. Z. R. Agustina and T.-H. Cheng, "How Students' Perspectives about Online Learning Amid the COVID-19 Pandemic?," Studies in Learning and Teaching, vol. 1, no. 3, pp. 133-139, 2020.

[32] L. J. Moleong, "Metode Penelitian Kualitatif, Bandung: Remaja Rosdakarya," ed: Mosal, 2013.

[33] Purwanto, Evaluasi hasil belajar. Pustaka Pelajar, 2009.

[34] S. M. Tamah, K. R. Triwidayati, and T. S. D. Utami, "Secondary school language teachers' online learning engagement during the COVID-19 pandemic in Indonesia," Journal of Information Technology Education: Research, vol. 19, pp. 803-832, 2020.

[35] R. Bhaumik and A. Priyadarshini, "E-readiness of senior secondary school learners to online learning transition amid COVID-19 lockdown," Asian Journal of Distance Education, vol. 15 , no. 1, pp. 244-256, 2020. 